\title{
Implementasi Pembelajaran Bahasa Inggris Berbasis Tematik Terpadu Bagi Siswa Sekolah Dasar
}

\author{
Meiliana Nurfitriani ${ }^{1}$, Mohammad Fahmi Nugraha ${ }^{1,2}$, Budi Hendrawan ${ }^{1}$ \\ ${ }^{1}$ Universitas Muhammadiyah Tasikmalaya, ${ }^{2}$ Universitas Negeri Jakarta \\ ${ }^{1}$ Jl. Tamansari KM. 2,5 Kota Tasikmalaya 46196 \\ ${ }^{2} J$ l. Rawamangun Muka, RT.11/RW.14, Rawamangun, Pulo Gadung, Kota Jakarta Timur, \\ Daerah Khusus Ibukota Jakarta 13220 \\ ${ }^{*}$ Corresponding Email: meiliana.nurfitriani@umtas.ac.id
}

\begin{abstract}
This study aims to determine how integrated thematic-based English learning is for elementary school students. The method used is a qualitative research method with descriptive analysis techniques with library research by examining the implementation of integrated thematic-based English learning for elementary school students. Data collection is done by reducing documents in the form of reports, news and research articles both nationally and internationally related to the topic of this research article. The results showed that the integration between student experience and previous knowledge possessed by children with English learning presented in a theme, will help children to gain knowledge, skills, and attitudes holistically. The theme developed is of course taking into account the children's knowledge, interests, and environment. Each skill in English is also not taught separately but is learned in an integrated manner with other skills. Therefore, the concept of learning English as a foreign language in accordance with the concept of an integrated thematic approach will be able to provide the value of knowledge, skills, and attitudes as a whole whose process is in line with the characteristics of children at the elementary school level.
\end{abstract}

\section{Keywords}

English Learning, Integrated Thematic, Elementary School

\begin{abstract}
Abstrak
Penelitian ini bertujuan untuk mengetahui bagaimana pembelajaran bahasa inggris berbasis tematik terpadu bagi siswa sekolah dasar. Metode yang digunakan merupakan metode penelitian kualitatif dengan teknik analisis deskriptif dengan kajian kepustakaan (library research) dengan mengkaji implementasi pembelajaran bahasa inggris berbasis tematik terpadu bagi siswa sekolah dasar. Pengumpulan data dilakukan dengan cara mereduksi dokumen berupa laporan-laporan, berita-berita serta artikel-artikel penelitian baik nasional maupun internasional yang berkaitan dengan topik artikel penelitian ini. Hasil penelitian menunjukkan bahwa Keterpaduan antara pengalaman siswa dan pengetahan yang dimiliki oleh anak sebelumnya dengan pembelajaran bahasa Inggris yang disajikan dalam sebuah tema, akan membantu anak dalam mendapatkan nilai pengetahuan, keterampilan, dan sikap secara holistik. Tema yang dikembangkan tentunya dengan mempertimbangkan pengetahuan, minat, dan lingkungan anak. Setiap skills dalam bahasa Inggris juga tidak diajarkan secara terpisah namun dipelajari secara terintegrasi dengan skill lainnya. Oleh karena itu, konsep pembelajaran bahasa Inggris sebagai bahasa asing yang sesuai dengan konsep pendekatan tematik terpadu akan mampu memberikan nilai pengetahuan, keterampilan, dan sikap secara menyeluruh yang prosesnya sejalan dengan karakteristik anak tingkat sekolah dasar.
\end{abstract}

Kata Kunci

Pembelajaran Bahasa Inggris, Tematik Terpadu, Sekolah Dasar

\section{A. PENDAHULUAN}

Bahasa Inggris merupakan bahasa internasional yang kedudukannya menempati peranan yang sangat penting di era global saat ini. Berdasarkan laporan Ethnologue: Language of the world tahun 2021 bahwa 1,348 milyar orang menggunakan bahasa 
Inggris sebagai alat komunikasi, baik sebagai bahasa pertama maupun bahasa kedua(web Ethnologue, 2021), sehingga bisa dikatakan bahwa bahasa Inggris adalah bahasa yang paling banyak digunakan di dunia. Seiring dengan hal tersebut, maka segala informasi dalam berbagai bidang kehidupan seperti pendidikan, ekonomi, teknologi, politik, dan bisnis disajikan dalam Bahasa Inggris (Nurfitriani, 2020). Hal ini menjadi motivasi yang penting bagi setiap orang untuk mempelajari bahasa Inggris agar dapat mengikuti perkembangan ilmu pengetahuan dan teknologi yang berkembang secara pesat.

Bahasa Inggris sebagai bahasa asing di Indonesia sangat populer untuk menjadi bahasa yang harus dipelajari oleh peserta didik dengan harapan mereka dapat ikut bersaing di era modern ini. Orang tua siswa cenderung menyekolahkan anak-anak mereka di sekolah yang memiliki prestasi di tingkat international dan memasukkan bahasa Inggris ke dalam kurikulum sekolah tersebut. Tidak hanya itu, anakanak mereka sejak dini juga diberikan kursus bahasa Inggris di luar jam sekolah agar mereka memiliki kemampuan berbahasa Inggris yang baik. Hal tersebut juga didukung oleh kebijakan dari pemerintah terkait status mata pelajaran bahasa Inggris di sekolah dasar. Pemerintah sempat melakukan perubahan kurikulum dari kurikulum KTSP (kurikulum Tingkat Satuan Pendidikan) dimana Bahasa Inggris menjadi mata pelajaran muatan lokal (mulok) yang wajib dipelajari, dirubah menjadi kurikulum 2013 yang meniadakan Bahasa Inggris dalam mata pelajaran mulok. Hal tersebut menimbulkan banyak pro kontra yang pada akhirnya pada tahun 2014, kementrian pendidikan merevisi kebijakannya terkait kurikulum tersebut, sehingga bagi sekolah yang menerapkan kurikulum 2013 tetap memasukkan bahasa Inggris sebagai mulok (Faridatuunisa, 2020). Hal tersebut menunjukkan bahwa kesadaran masyarakat dan dukungan pemerintah akan pentingnya memiliki kemampuan berbahasa Inggris sangat tinggi, dan dianggap sebagai suatu kebutuhan untuk menjawab perkembangan zaman.

Namun dalam praktiknya, Bahasa Inggris kerapkali menjadi tantangan besar baik bagi English learner (pelajar) maupun bagi guru Bahasa Inggris itu sendiri. Kebanyakan siswa menganggap bahwa Bahasa Inggris merupakan mata pelajaran yang sulit dipelajari. Bahasa Inggris dianggap terlalu kompleks karena siswa harus menghapalkan kosakata baru dan menyusun kata tersebut menjadi kalimat yang bermakna sesuai dengan aturan bahasa Inggris (Grammar). Hal ini sesuai dengan hasil penelitian Tambunsaribu (Jurnal Dialektika: 2020) terkait masalah yang dihadapi pelajar Bahasa Inggris dalam memahami pelajaran bahasa Inggris. Beliau menyatakan bahwa $77 \%$ siswa menganggap Bahasa Inggris itu sulit dipelajari dan membingungkan, dalam hal ini 66\% siswa menyebutkan bahwa yang menjadi kendalanya adalah penerapan tata bahasa (grammar). Selain itu, implementasi pembelajaran Bahasa Inggris di sekolah dasar secara real belum maksimal. Kebijakan pemerintah dalam penerapan pembelajaran Bahasa Inggris masih perlu arahan dan diawasi secara langsung oleh dinas Pendidikan, terlebih lagi banyak sekali guru yang mengajar Bahasa Inggris di Sekolah Dasar bukan lulusan Si Pendidikan Bahasa Inggris, sehingga dari segi kompetensi, guru kurang mumpuni 
dalam mengajarkan bahasa Ingris terhadap siswa secara professional. Selain itu, penerapan pembelajaran bahasa Inggris di SD berjalan menurut versi masing masing, ada ketidakseragaman dari sisi kapan pemberlakuan mata pelajaran Bahasa Inggris mulai diajarkan karena ada sekolah yang mulai dari kelas 1 SD dan ada juga yang mulai dari kelas 4 SD sehingga ada ketidakseragaman materi yang diajarkan. Pemberian jenis soal harian, UTS, UAS, pengadaan sarana dan prasarana, hingga metode pun diserahkan sepenuhnya kepada kemampuan guru pengampu mata pelajaran tersebut seadanya. Hal ini dirasa kurang efektif dan tidak akan memberikan hasil belajar yang optimal bagi siswa. Oleh karena itu dibutuhkan rancangan penerapan pembelajaran Bahasa Inggris yang sesuai dengan kurikulum yang saat ini digunakan di Sekolah Dasar yaitu pembelajaran Bahasa Inggris berbasis tematik terpadu.

Pembelajaran tematik terpadu merupakan model pembelajaran yang berbasis tema dengan mengintegrasikan beberapa mata pelajaran didalamnya. Hal ini sesuai dengan pendapat Rusman (2015) bahwa pembelajaran tematik terpadu dikemas dalam bentuk tematema yang memuat beberapa mata pelajaran yang dintegrasikan untuk mengenalkan berbagai konsep materi secara menyeluruh terhadap anak didik sehingga pembelajaran akan menjadi lebih bermakna dan mudah dipahami. Dalam hal ini, maka teori-teori dalam mata pelajaran di sekolah dapat dikaitkan dengan kehidupan nyata siswa. Bahasa Inggris sebagai mata pelajaran yang bersifat praktis dirasa sangat relevan dengan model tematik terpadu sehingga siswa bisa secara langsung mempraktekkan skill berbahasa Inggris mereka sesuai dengan konteksnya. Richard (2002) menyatakan bahwa bahasa adalah komunikasi, dan sangat penting bagi seorang guru untuk mengembangkan kemampuan berkomunikasi secara efektif dalam berbagai konteks professional dan sosial dalam diri siswa. Oleh karena itu, penerapan pembelajaran bahasa Inggris berbasis tematik terpadu perlu dirancang dengan baik untuk merespon berbagai perubahan kebutuhan siswa dan menjadikannya pembelajar aktif dalam proses pembelajaran bahasa.

\section{B. HASIL DAN PEMBAHASAN}

\section{Hasil}

Pembelajaran Bahasa Inggris pada tingkat sekolah dasar merupakan salah satu upaya untuk menyiapkan siswa mampu berpartisipasi di era global, dan siap untuk menyerap ilmu pengetahuan dan teknologi. Untuk itu, siswa diharapkan memiliki kemampuan bahasa inggris yang baik, secara lisan maupun tulisan. Dalam Bahasa Inggris, ada 4 keterampilan yang harus dicapai, yaitu productive skills yang terdiri dari Speaking (berbicara) dan writing (menulis), serta receptive skills yang terdiri dari Listening (mendengarkan) dan Reading (Membaca). Seseorang dikatakan mampu berbahasa Inggris yang baik jika mampu menguasai ke empat skills tersebut.

Pembelajaran bahasa Inggris sebagai bahasa asing idealnya dikenalkan terhadap anak sejak usia dini. Maka pembelajaran bahasa Inggris sudah bisa dilaksanakan di sekolah dasar. Hal ini sangat didukung oleh sebuah teori hipotesis umur kritis (Critical Age Hypothesis) yang menyatakan bahwa sebelum mencapai umur 12 tahun, anak mempunyai kemampuan untuk memperoleh bahasa mana pun yang disajikan padanya 
secara natif, hal ini tampak terutama pada aksennya (Djardjowidjojo, 2005). Berdasarkan teori tersebut bahwa anak usia 2 sampai 12 tahun akan dapat dengan mudah mempelajari berbagai macam bahasa dengan kemampuan seperti penutur asli. Hal ini bisa terjadi karena pada usia tersebut belum ada proses lateralisasi atau pembagian tugas antara otak kiri dan otak kanan. Dalam kondisi demikian, keadaan otak masih elastis sehingga otak bisa menerima tugas apapun, termasuk mempelajari bahasa asing.

Selain itu, menurut Chomsky (1999) bahwa manusia mempunyai faculties of mind yakni semacam kapling-kapling intelektual di dalam otaknya. Salah satu kapling itu dilengkapi dengan sebuah piranti yang disebut dengan istilah Language Acquisition Device (LAD) yang digunakan khusus untuk pemerolehan bahasa secara alamiah, dan piranti ini sudah dikaruniakan Tuhan sejak lahir. Berdasarkan teori tersebut, maka dengan adanya LAD, setiap orang dapat dengan mudah mempelajari bahasa apapun, sedangkan lingkungan belajar hanyalah menjadi stimulus untuk dapat mengaktifkan LAD tersebut (Djardjowidjojo, 2005). Dengan kata lain, bahasa asing dapat dengan mudah dipelajari pada awal perkembangan anak usia sekolah dasar.

Pembelajaran bahasa Inggris pada anak harus sesuai dengan tingkat perkembangan mereka. Pada setiap tahapan perkembangan, anak-anak memiliki karakteristik tertentu yang harus dipahami agar proses pembelajarannya dapat berlangsung lebih optimal. Beberapa karakteristik anak menurut Scott \& Ytreberg (2003) adalah bahwa mereka sangat aktif secara fisik, pemahaman mereka itu muncul melalui aktifitas yang dikerjakan secara langsung melalui tangan, mata, dan telinga mereka. Namun rentang konsentrasi anak sangat pendek sehingga anak cenderung bosan saat melakukan sesuatu. Oleh karena itu diperlukan berbagai variasi dalam proses pembelajaran. Selain itu, anakanak senang sekali akan suatu hal yang bersifat konkrit, sangat antusias dan berpikir positif dalam proses pembelajaran, serta senang melakukan sesuatu hal yang menyenangkan seperti bermain. Sejatinya memang dunia anakanak adalah bermain. Oleh karena itu dalam proses pembelajaran bahasa Inggris sangat penting untuk mengintegrasikan pembelajaran ke dalam dunia bermain anak-anak.

Pada hakikatnya, pembelajaran bahasa Inggris pada anak dapat berjalan secara maksimal jika proses belajar bahasa tersebut berlangsung secara fungsional dan kontekstual (Richard, 2002). Dalam hal ini, bahasa asing bukanlah teori yang hanya untuk dipahami, namun merupakan suatu hal yang harus dipraktekkan dan diberi umpan balik secara personal sehingga anak bisa langsung mempraktekkan bahasa yang dipelajari sesuai tidak dengan fungsi dan konteksnya. Konteks yang dimaksud berupa situasi social dan budaya, permainan, nyanyian, dongeng, dan pengalaman. Hal tersebut merupakan proses yang terjadi dalam pembelajaran bahasa untuk melihat pemahaman mereka terkait aturan kebahasaan yang disesuaikan dengan dunianya.

Pembelajaran bahasa Inggris sebagai bahasa asing juga harus realistis dan otentik. Piaget menyatakan bahwa anak-anak pada jenjang sekolah dasar berada pada tahap concrete operational. Pada tahap ini anak-anak lebih mudah memahami suatu hal yang praktis dan konkrit dalam lingkungannya. Dalam proses pembelajarannya, anak-anak 
dilibatkan secara langsung dengan bahasa dari sesuatu yang mereka sudah ketahui sebelumnya dan ada di lingkungannya sehingga hal tersebut terasa nyata dan mudah dipahami (Cameron, 2001). Dalam prinsip ini pun, lingkungan menjadi sumber belajar utama sehingga anak dapat mengamati, mencari informasi, dan memecahkan masalah untuk mengembangkan pengetahuan dan keterampilan berbahasa mereka. Oleh karena itu, berdasarkan prinsip ini, learning by doing menjadi suatu cara yang efektif untuk diterapkan dalam belajar bahasa Inggris.

Kurikulum di sekolah dasar saat ini menggunakan kurikulum 2013 revisi 2017, hal tersebut sesuai dengan kebijakan Kementerian Pendidikan dan Kebudayaan Republik Indonesia (Kemendikbud RI), yang menjadi ciri khas penerapan kurikulum 2013 di sekolah dasar adalah penggunaan pendekatan pebelajaran tematik terpadu, Kurikulum tematik terpadu dapat diartikan suatu kegiatan pembelajaran dengan mengintegrasikan materi beberapa mata pelajaran dalam satu tema/topik/pembahasan. Pembelajaran tematik merupakan satu usaha untuk mengintegrasikan pengetahuan, keterampilan, nilai, atau sikap pembelajaran, serta kreativitas dengan menggunakan tema. Secara etimologi, kurikulum tematik terpadu terdiri dari dua kata, yaitu kurikulum dan terpadu (Juanda, 2019). Ciri khas dalam pendekatan pembelajaran tematik terpadu adalah penggunaan tema dalam pembelajarannya sehingga tidak batas antar setiap mata pelajaran nyaris tidak terlihat, hal tersebut dimaksudkan supaya para siswa dapat memiliki sikap analisis yang lebih mendalam serta mampu menerapkan hasil belajarnya dalam kehidupan sehari-hari. Pada dasarnya setiap anak memiliki kemampuan kreatif, untuk itulah diperlukan metode pembelajaran tematik dengan menggunakan pendekatan lintas disiplin ilmu yang disusun secara berkesinambungan sehingga dapat mengakomodasi kebutuhan siswa. Pembelajaran tematik menekankan partisipasi aktif peserta didik yang sedang mengalami proses pembelajaran berfikir, emosi, dan sosial (Mukhlis, 2012).

Menurut Kemendikbud RI (2013), pelaksanaan pembelajaran tematik terpadu memiliki lima prinsip yaitu:

1. Pembelajaran tematik integratif memiliki satu tema yang aktual dekat dengan dunia siswa dan ada dalam kehidupan sehari-hari. Tema ini menjadi satu pemersatu materi yang beragam dari beberapa mata pelajaran.

2. Pembelajaran tematik integratif perlu memilih materi beberapa mata pelajaran yang mungkin saling terkait. Dengan demikian materimateri yang di pilih dapat mengungkapkan tema secara bermakna. Mungkin terjadi pengayaan horizontal dalam bentuk contoh aplikasi yang tidak termuat dalam standart isi. Namun ingat, penyajian materi pengayaan seperti ini perlu di batasi dengan mengacu pada tujuan pembelajaran.

3. Pembelajaran tematik integratif tidak boleh bertentangan dengan tujuan kurikulum yang berlaku tetapi sebaliknya pembelajaran tematik integratif harus mendukung pencapaian tujuan utuh kegiatan penbelajaran yang termuat dalam kurikulum.

4. Materi pembelajaran yang dapat di padukan dalam satu tema selalu mempertimbangkan karakteristik 
siswa seperti minat, kemampuan, kebutuhan, dan pengetahuan awal.

5. Materi awal yang dipadukan tidak terlalu dipaksakan. Artinya, materi yang tidak mungkin dipadukan tidak usah dipadukan (Hidayah, 2015).

Adapun manfaat pembelajaran tematik terpadu menurut Poerwadarminta (1983) dalam (Hidayah, 2015) mengatakan bahwa pembelajaran ini memberikan banyak keuntungan, di antaranya:

1. Siswa mudah memusatkan perhatian pada suatu tema tertentu,

2. Siswa mampu mempelajari pengetahuan dan mengembangkan berbagai kompetensi dasar antar mata pelajaran dalam tema yang sama;

3. Pemahaman terhadap materi pelajaran lebih mendalam dan berkesan;

4. Kompetensi dasar dapat dikembangkan lebih baik dengan mengkaitkan mata pelajaran lain dengan pengalaman pribadi siswa;

5. Siswa mampu lebih merasakan manfaat dan makna belajar karena materi disajikan dalam konteks tema yang jelas;

6. Siswa lebih bergairah belajar karena dapat berkomunikasi dalam situasi nyata, untuk mengembangkan suatu kemampuan dalam satu mata pelajaran sekaligus mempelajari matapelajaran lain;

7. Guru dapat menghemat waktu karena mata pelajaran yang disajikan secara tematik dapat dipersiapkaan sekaligus dan diberikan dalam dua atau tiga pertemuan, waktu selebihnya dapat digunakan untuk kegiatan remedial, pemantapan, atau pengayaan.

\section{Pembahasan}

Pembelajaran bahasa Inggris di sekolah tentunya tidak lepas dari kurikulum yang digunakan di sekolah tersebut. Demi tercapainya tujuan pembelajaran bahasa yang optimal, diperlukan sebuah pendekatan yang mampu memfasilitasi siswa untuk mencapai proses pembelajaran yang lebih bermakna, hingga pada akhirnya siswa mampu menguasai ke empat skills Bahasa Inggris secara menyeluruh.

Pelaksanaan pembelajaran tematik terpadu tentunya memerlukan peran penting dari guru sebagai fasilitator, guru hendaknya lebih meningkatkan dan mengembangkan perencanaan, pelaksanaan dan penilaian pembelajaran dengan menerapkan pendekatan saintifik pada pembelajaran tematik terpadu sesuai ketentuan yang berlaku, sehingga pembelajaran akan lebih efektif. Guru sebelum melaksanakan kegiatan perlu adanya perencanaan yaitu dengan menyusun RPP. Dengan perencanaan pembelajaran yang matang, maka pelaksanaan pembelajaran juga dapat berjalan dengan optimal serta membawa dampak baik terhadap siswa. Hal ini dapat menjadikan siswa lebih berpikir kritis, kreatif, dan inovatif (Sari et al., 2018). Selain itu Saran yang diberikan adalah guru, bersama dengan sekolah dan dinas terkait hendaknya mengembangkan dan menambah pengetahuan tentang implementasi pembelajaran tematik terpadu, cara penerapan kegiatan saintifik, serta cara pelaksanaan penilaian otentik melalui KKG, atau seminar kurikulum 2013. Kepala sekolah hendaknya memotivasi guru agar dapat mengembangkan dan melaksanakan pembelajaran tematik terpadu dengan lebih baik, terutama berkaitan dengan kegiatan penilaian (Syaifuddin, 2017).

C. KESIMPULAN

Berdasarkan Pengkajian tentang implementasi pembelajaran Bahasa 
Inggris berbasis tematik terpadu, maka tematik terpadu merupakan suatu pendekatan yang mampu mengembangkan kemampuan bahasa Inggris anak sekolah dasar. Dalam proses pembelajarannya, anak disajikan beberapa mata pelajaran dalam satu tema tertentu sehingga pembelajaran menjadi lebih bermakna dan kontekstual. Keterpaduan antara pengalaman siswa dan pengetahan yang dimiliki oleh anak sebelumnya dengan pembelajaran bahasa Inggris yang disajikan dalam sebuah tema, akan membantu anak dalam mendapatkan nilai pengetahuan, keterampilan, dan sikap secara holistik. Tema yang dikembangkan tentunya dengan mempertimbangkan pengetahuan, minat, dan lingkungan anak. Setiap skills dalam bahasa Inggris juga tidak diajarkan secara terpisah namun dipelajari secara terintegrasi dengan skill lainnya. Oleh karena itu, konsep pembelajaran bahasa Inggris sebagai bahasa asing yang sesuai dengan konsep pendekatan tematik terpadu akan mampu memberikan nilai pengetahuan, keterampilan, dan sikap secara menyeluruh yang prosesnya sejalan dengan karakteristik anak tingkat sekolah dasar.

\section{DAFTAR PUSTAKA}

Cameron, Lynne. 2001. Teaching English to Young Learners. USA: Cambridge University Press.

Dardjowidjojo, Soenjono. 2005. Psikolinguistik: Pengantar Pemahaman Bahasa Manusia. Jakarta: Yayasan Obor Indonesia.

Ethnologue.com.

https://www.ethnologue.com/guid es/most-spoken-languages

Faridatuunisa, Ichda. 2020. Kebijakan dan Pelaksanaan pembelajaran
Bahasa Inggris untuk SD di Indonesia. Prosiding Seminar Nasional: Implementasi Merdeka Belajar berdasarkan Ajaran Taman Siswa, Vol.1 no.1, Hal. 194

Hidayah, N. (2015). Pembelajaran Tematik Integratif di Sekolah Dasar. TERAMPIL Pendidikan Dan Pembelajaran Dasar, 2, 33-49.

Juanda, A. (2019). Pembelajaran Kurikulum Tematik Terpadu. In Teori dan praktik Pembelajara Tematik Terpadu Beroientasi Landasan Filosofis, Psikologis dan Pedagogis.

Mukhlis, M. (2012). Pembelajaran Tematik PEMBELAJARAN TEMATIK Mohamad Muklis STAIN Samarinda. Fenomena, IV(20), 6376. https://doi.org/10.1002/pro.215

Nurfitriani, Meiliana dkk. 2020. Pengantar Pendidikan dan Pembelajaran di Sekolah Dasar. Tasikmalaya: Edu Publisher.

Richard, Jack C \& Renandya, Willy A. 2002. Methodology in Language Teaching: An Anthology of Current Practice. USA: Cambridge University Press.

Rusman. 2015. Pembelajaran Tematik Terpadu: Teori Praktik dan Penilaian. Jakarta: Rajawali Pers.

Sari, N. A., Akbar, S., \& Yuniastuti. (2018). Penerapan pembelajaran tematik terpadu di sekolah dasar. Journal.Um.Ac.Id, 3(12), 1572-1582. http://journal.um.ac.id/index.php/ jptpp/article/view/11796

Scott, W.A., \& Ytreberg, L.H,. 2003.Teaching English to Children. New York: Longman

Syaifuddin, M. (2017). Implementasi Pembelajaran Tematik di Kelas 2 SD Negeri Demangan Yogyakarta. 
Tadris: Jurnal Keguruan Dan Ilmu Tarbiyah, 2(2), 139 . https://doi.org/10.24042/tadris.v2i 2.2142

Tambunsaribu, Gunadwan dkk. 2001. Masalah yang Dihadapi Pelajar Bahasa Inggris Dalam Memahami Pelajaran Bahasa Inggris. Dialektika Jurnal Bahasa Sastra dan Budaya. Vol. 8 No1 